\author{
URSZULA MARIA MARCINKOWSKA \\ Instytut Zdrowia Publicznego \\ Wydziat Nauk o Zdrowiu \\ Uniwersytet Jagielloński - Collegium Medicum \\ Grzegórzecka 20, 31-531 Kraków \\ Yale Reproductive Lab \\ Department of Anthropology \\ Sachem 10, 06511 New Haven, USA \\ E-mail: ummarcinkowska@gmail.com
}

\title{
CZY W OKRESIE WYSOKIEJ PEODNOŚCI KOBIETY POSZUKUJĄ CECH SYGNALIZUJĄCYCH DOBRE GENY?
}

\section{WSTEP}

Choć atrakcyjność fizyczna nie jest najważniejsza, to jednak może przekładać się na społeczne doświadczenia i konkretne efekty w życiu. Jest kluczową częścia doboru płciowego człowieka i jako taka jest również przedmiotem badań behawioralnych (np. PERRETT 2010). Naukowe zainteresowanie atrakcyjnościa opiera się na oczekiwanym jej związu z wartością biologiczną i sukcesem reprodukcyjnym (np. SyMONS 1995), dlatego zarówno sposób definiowania atrakcyjności, jak i nasze preferencje miałyby wartość adaptacyjną. Co więcej, na cechy sygnalizujace wysoka jakość genetyczną, tzn. dobre geny, powinniśmy szczególnie być wrażliwi w okresie reprodukcyjnym, w którym spłodzenie potomstwa jest możliwe (okres ten ujmować można zarówno w skali życia, tj. wiek reprodukcyjny, jak i w skali miesięcznych wahań płodności w trakcie cyklu menstruacyjnego u kobiet). „Dobre geny” przekazane potomstwu zwiększyłyby jego przeżywalność $i$ dostosowanie (ang. fitness), m.in. wpływając na zwiększenie atrakcyjności i zwiąane $z$ tym większe szanse na efektywna reprodukcje (tzw. Hipoteza Seksownych Synów) (FISHER 1930).

Płodność kobiety w danym momencie zależy od różnych czynników, w tym od poziomu hormonów płciowych, których stężenie zmienia się znaczaco na przestrzeni całego cyklu menstruacyjnego. $\mathrm{Na}$ podstawie tego kluczowego czynnika można stwierdzić, czy zapłodnienie jest prawdopodobne. $Z$ drugiej strony, hormony płciowe warunkuja zachowanie i preferencje seksualne. Cykliczne zmiany preferencji w okresie cyklu menstruacyjnego uważane sa za istotna cechę doboru seksualnego. Wynika to $z$ faktu, że kierunkuja one uwagę kobiety na wskazówki mówiace o „dobrych genach" partnera w czasie, gdy zapłodnienie jest najbardziej prawdopodobne (THORNHILL i GANGESTAD 1999), a więc w jedynym, konkretnym momencie całego cyklu, kiedy kobieta może zapewnić „dobre geny” dla swojego potomstwa.

\section{SYMETRIA I MESKIE CECHY TWARZY JAKO WYZNACZNIKI DOBRYCH GENOW}

Przyjmując założenie, że to, co uznajemy za atrakcyjne, powinno w jakiś sposób być biologicznie korzystne (dla nas albo dla naszego potomstwa), wielu badaczy podjęło próbę odkrycia kryteriów atrakcyjności. Jednym $z$ czynników decydujących o tym, co uznajemy za atrakcyjne jest stopień dymorfizmu płciowego. Mężczyźni cechują się m.in. mocniej zarysowanymi kośćmi policzkowymi oraz wydatniejszymi łukami brwiowymi i żuchwa, co warunkowane jest poziomem hormonow płciowych (testosteronu) w toku życia, a przede wszystkim w 
okresie dojrzewania. Męskie rysy twarzy sa skorelowane $z$ poziomem testosteronu we krwi również w życiu dorosłym (POUND i współaut. 2009). Z drugiej strony, hormon ten jest stresorem dla układu odpornościowego, a jego wysoki poziom może upośledzić funkcjonowanie systemu immunologicznego. Uwzględnienie obu tych właściwości skłania do przyjęcia, iż jedynie u immunokompetentnych mężczyzn (czyli takich, którzy są w stanie efektywnie zwalczać infekcje i patogeny) będzie możliwe utrzymywanie wysokiego poziomu testosteronu (ZAHAVI 1975). W związku $z$ powyższym można założyć, że wyraziste cechy płciowe będą rzetelnym wskaźnikiem dziedzicznej odporności, jednak nie wszystkie wyniki badań potwierdzają takie założenie (ScOTT i współaut. 2013). Ponadto, silnie zmaskulinizowani mężczyźni charakteryzują się mniejszą stałością w zwiazkach, silniejszą dyspozycja do przelotnych romansów i większa otwartością seksualną (BOOTHROYD i współaut. 2008). Preferowanie męskich partnerów zdaje się być wyborem dobrych genów dla przyszłego potomstwa za cenę stałego, zaangażowanego partnera.

Uważa się, że prócz męskich cech twarzy, markerem dobrego stanu somatycznego i prawidłowego rozwoju może być symetria ciała. Organizm dysponuje ograniczonymi zasobami energetycznymi. Podczas wzrostu konieczne jest więc ich rozdysponowanie pomiędzy różne równocześnie przebiegające procesy (zarówno somatyczne, jak i metaboliczne). W przypadku niedoboru energii, albo w przypadku, gdy organizm nie rozdziela posiadanych zasobów efektywnie, zaburzeniu może ulec symetryczny rozwój dwuboczny. Innymi słowy im bardziej asymetryczny jest dorosły organizm, tym więcej chorób lub trudności rozwojowych musiał napotkać (RHODES i współaut. 2001).

\section{GDZIE I KIEDY MOŻE ZAISTNIEĆ ZMIANA PREFERENCJI}

Chociaż teoria cyklicznych zmian preferencji kobiet $\mathrm{w}$ stosunku do cech męskich nie jest nowa, nadal nie udało się osiagnaćc konsensusu w kwestii istnienia takich wahań. Wiele badań wykazało, że kobiety faktycznie wykazuja silniejsza preferencję symetrii i cech męskich w okresie owulacji oraz $\mathrm{w}$ jego bezpośrednim sasiedztwie czasowym, czyli w czasie tzw. dni płodnych (GANGESTAD i THORNHILL 1998). Jednocześnie wyniki innych badań poddaja w wattpliwość istnienie takich cyklicznych zmian (MARCINKOWSKA i współaut. 2017). Niektóre $z$ nich wykazały istnienie zmian preferencji męskich cech, ale wyłącznie w kontekście oceny mężczyzny jako potencjalnego partnera w krótkoterminowej relacji seksualnej (w relacji długoterminowej tego typu zmian preferencji nie zaobserwowano) (LitTle i Jones 2012). Oznacza to, że płodne kobiety $\mathrm{w}$ większym stopniu kierowały swoja uwage na bardziej męskie cechy tylko wtedy, gdy szukały partnera na randkę albo krótkoterminowy związek o charakterze erotycznym. W innych badaniach wykazano cykliczne wahania, jednak były one widoczne wyłącznie w przypadku, gdy oceny dokonywały kobiety pozostajace w stałym związku (LitTLE i współaut. 2008). Mogło to wynikać z sytuacji, w których dopiero po zdobyciu stałego partnera oraz gwarancji opieki nad ewentualnym potomstwem (w razie gdyby się pojawiło), kobiety zaczynaja szukać „dobrych genów” (znajdowanych u mężczyzn, którzy będa mniej skłonni do inwestowania w stały związek lub potomstwo). Możliwe jest również, że takie wahania, jeśli już się pojawią, będa częstsze u kobiet, które uważaja się za atrakcyjne (LitTLE I MANNION 2006). Większa atrakcyjność (rozumiana jako np. bycie bardziej kobieca lub zdrowa) podnosi szanse pozyskania partnera o lepszej jakości genetycznej. Co więcej, seksualna otwartość (np. bycie bardziej zorientowana na krótkotrwałe związki) okazała się dodatnio skorelowana $z$ preferowaniem męskości przez kobiety (LiTTLE i JoNEs 2012).

\section{MIESZANE WYNIKI}

W wielu badaniach nie wykazano cyklicznych zmian preferencji. Podobnie w przypadku metaanaliz opartych na wszystkich opublikowanych badaniach dotyczacych zmian preferencji w cyklu (GILDERSLEEVE i współaut. 2014, Wood i współaut. 2014). Ponadto, sama hipoteza cyklicznych wahan, czyli wybór osobników na podstawie markerów „dobrych genów”, w okresie płodnym opartym na zmiennym poziomie hormonów płciowych, również została poddana $\mathrm{w}$ wątpliwość. Zasugerowano, iż obserwowane zmiany moga nie być adaptacjami per se. Zamiast tego miałyby być produktami ubocznymi związanymi $z$ różnicami pomiędzy kobietami w zakresie potencjału reprodukcyjnego i poziomu hormonów płciowych (HAVLICEK i współaut. 2015).

W niektórych najnowszych badaniach nie znaleziono potwierdzenia cyklicznych zmian preferencji kobiet odnośnie wskaźników jakości genetycznej mężczyzn, tj. poziomu maskulinizacji czy symetrii (MARCINKOWSKA i współaut. 2017). Jednym $z$ możliwych wyjaśnień braku zmienności może być fakt, że osoby badane były ogólnie zadowolone ze 
swoich związków oraz uważały swoich partnerów za atrakcyjnych i męskich. Ponieważ okołoowulacyjne wahania wyjaśnia się w kategoriach poszukiwania „dobrych genów, (szczególnie w kontekście krótkoterminowych związków erotycznych), to jest możliwe, że uczestniczki będace w związku, nie były zainteresowane lepszymi genami $z$ uwagi na fakt posiadania satysfakcjonujacego partnera. Kolejnym możliwym wyjaśnieniem braku wzrostu preferencji cech męskich w okresie płodnym jest podważenie trafności wskaźnika „dobrych genów”, jakim miałyby być męskie cechy twarzy (MOORE i współaut. 2011).

Przyjmujac szerszy punkt widzenia można uznać, że zachowanie i preferencje kobiet nie sa tak wrażliwe na dobowe zmiany hormonalne, jak się wcześniej uważało. W takiej sytuacji to całokształt profilu hormonalnego oraz ogólny stan płodności (np. średni poziom progesteronu $w$ fazie lutealnej albo pojawienie się owulacji w trakcie cyklu) byłyby bardziej przydatne w poszukiwaniu korelatów preferencji męskości i określaniu cech, które kobiety odbieraja jako atrakcyjne u mężczyzn (MARCINKOWSKA i współaut. 2018).

\section{WNIOSKI}

W opublikowanej dotychczas literaturze brakuje konsensusu w kwestii tego, czy preferencje kobiet $\mathrm{w}$ trakcie cyklu zmieniają się w zależności od poziomu hormonów płciowych, a co za tym idzie płodności. Nie ulega wątpliwości, że zjawisko to jest bardziej złożone niż początkowo sązono. Wahania, jeśli już się pojawiaja, moga manifestować się wyłącznie w pewnych kontekstach (np. w przypadku krótkiego związku seksualnego) czy tylko u pewnych osób (tj. osób będacych w związkach i cechujacych się wysokim poczuciem własnej atrakcyjności). Zmiany preferencji moga również wcale nie zachodzić, będac jedynie produktem ubocznym różnic międzyosobniczych. Niezależnie od natury mechanizmu tego zjawiska, jego poznanie wymaga dalszych badań. Powinny one cechować się dokładniejszymi technikami pomiaru poziomu hormonów i większą liczebnościa badanych, co pozwoliłoby na uwzględnienie wielu zmiennych zakłócających. Niezbędne jest też przeprowadzenie większej liczby badań replikacyjnych na odmiennych, różnorodnych grupach. Jakkolwiek innowacyjność badawcza jest istotna dla zrozumienia natury człowiekas, to równie ważne sa badania weryfikujace prawdziwość istniejących już hipotez i zbliżonych do nich koncepcji $z$ wykorzystaniem nowych metod, a także wśród nowych populacji.

\section{Streszczenie}

Biologiczne podstawy atrakcyjności potencjalnych partnerów sa tematem licznych publikacji naukowych. Jedna $z$ weryfikowanych hipotez sa okołoowulacyjne zmiany preferencji kobiet $\mathrm{w}$ stosunku do markerów "dobrych genów”. Zgodnie $z$ tą hipoteza, w trakcie dni płodnych kobiety powinny uważać za atrakcyjne cechy stanowiące markery „dobrych genów”, które przekazane potomstwu zwiększyłyby jego przeżywalność i dostosowanie. Jako cechy będace markerami zostały zasugerowane m.in.: wysoki stopień maskulinizacji twarzy i symetria. Pomimo licznych badań publikowanych już od początku lat 90., a nawet kilku metaanaliz, brak jest jednoznacznego stanowiska odnośnie istotności, czy też istnienia takich zmian. W tym artykule pogladowym przedstawiono założenia i hipotezy cyklicznych zmian preferencji oraz wyjaśniono możliwe przyczyny rozbieżności wyników dotychczas opublikowanych badań.

\section{LITERATURA}

Boothroyd L. G., Jones B. C., BurT D. M., DeBRUINE L. M., PERRETT, D. I., 2008. Facial correlates of sociosexuality. Evol. Human Behav. 29, 211-218.

FISHER R. A., 1930. The genetical theory of natural selection. Clarendon Press, London.

Gangestad S. W., ThORNHILL R., 1998. Menstrual cycle variation in women's preferences for the scent of symmetrical men. Proc. Royal Soc. B: Biol. Sci. 265, 927-933.

Gildersleeve K., Haselton M. G., Fales M. R., 2014. Do women's mate preferences change across the ovulatory cycle? A meta-analytic review. Psychol. Bull. 140, 1205-1259.

HAVLICEK J., COBEY K. D., BARRETT L., KLAPILOVA K., ROBERTS S. C., 2015. The spandrels of Santa Barbara? A new perspective on the peri-ovulation paradigm. Behav. Ecol. 26, 12491260.

LitTle A. C., Mannion, H., 2006. Viewing attractive or unattractive same-sex individuals changes self-rated attractiveness and face preferences in women. Anim. Behav. 72, 981-987.

LitTle A. C., Jones B. C., 2012. Variation in facial masculinity and symmetry preferences across the menstrual cycle is moderated by relationship context. Psychoneuroendocrinology 37, 999-1008.

Little A. C., Jones B. C., DeBruine L. M., 2008. Preferences for variation in masculinity in real male faces change across the menstrual cycle: Women prefer more masculine faces when they are more fertile. Person. Individ. Differ. $45,478-482$.

MARCINKOWSKA U. M., GALBARCZYK A., JASIENSKA G., 2017. La donna e mobile? Lack of cyclical shifts in facial symmetry, and facial and body masculinity preferences-A hormone based stu$d y$. Psychoneuroendocrinology 88, 47-53.

MARCINKOWSKA U. M., KAMIŃSKI G., LiTTLE A. C., JASIENSKA G., 2018. Average ovarian hormone levels, rather than daily values and their fluctuations, are related to facial preferences among women. Horm. Behav. 102, 114-119.

MoORe F. R., CORNwell R. E., SMITH M. J., AL Dujaili E. A., SHARP M., PERRETT D. I., 2011. Evidence for the stress-linked immunocompetence handicap hypothesis in human male faces. Proc. Royal Soc. B: Biol. Sci. 278, 774780. 
PERRETT D. I., 2010. In your face: the new science of human attraction. Palgrave Macmillan, Houndmills, Hampshire.

Pound N., PEnTON-VOAK I. S., SuRridge A. K., 2009. Testosterone responses to competition in men are related to facial masculinity. Proc. Royal Soc. B: Biol. Sci. 276, 153.

Rhodes G., Yoshikawa S., Clark A., LeE K., MCKAY R., AKAMATSU S., 2001. Attractiveness of facial averageness and symmetry in non-Western cultures: In search of biologically based standards of beauty. Perception 30, 611625.

SCOTT I. M. L., ClARK A. P., BOOTHROYD L. G. PENTON-VOAK I. S., 2013. Do men's faces really signal heritable immunocompetence? Behav. Ecol. 24, 579-589.
SYMONS D., 1995. Beauty is in the adaptations of the beholder. The evolutionary psychology of human female attractiveness. [W:] Sexual nature, sexual culture. ABRAMSON P. R., PINKERTON S. D. (red.). The University of Chicago Press, Chicago, 80-118.

THORNHILl R., GANGESTAD S. W., 1999. Facial attractiveness. Trends Cognit. Sci. 3, 452-460.

Wood W., Kressel L., Joshi P. D., Louie B., 2014. Meta-analysis of menstrual cycle effects on women's mate preferences. Emot. Rev. 6, 229-249.

ZAHAVI A., 1975. Mate selection-A selection for a handicap. J.Theoret. Biol. 53, 205-214.

KOSMOS Vol. 68, 1, 103-106, 2019

URSZULA MARIA MARCINKOWSKA

Institute of Public Health, Faculty of Health Sciences, Jagiellonian University Medical College, Grzegórzecka str 20, 31-531 Cracow, Yale Reproductive Lab Department of Anthropology Sachem 10, 06511 New Haven, USA;

E-mail: ummarcinkowska@gmail.com

\section{DO WOMEN IN HIGH FERTILITY PHASE SEARCH FOR CUES OF “GOOD GENES” IN MAN?}

\section{Summary}

There have been some studies examining biological bases of what and why we find attractive in putative partners. One of the recently intensely studied fields is occurrence of peri-ovulatory shifts in women's preference towards cues to good genes in men. According to this theory, women in fertile days of the cycle would shift their attention towards cues to good genes - genes that would enhance the survival and fitness of their offspring. It has been suggested that among these cues, there is masculinity (exaggerated sexual dimorphism) and facial symmetry. Although there have been multiple studies since the 90' and multiple meta-analyses, consensus on whether such shift of preference exists is still lacking. This review article presents the assumptions behind the hypothesis of cyclical changes in preferences and explains possible reasons for discrepancies in the results of previously published studies.

Key words: attractiveness, fertility, human sexual selection, sexual preferences 